\title{
Chemosensory Performance of Molecularly Imprinted Fluorescent Conjugated
}

\section{Polymer Materials}

\author{
Jiahui Li, Claire E. Kendig, and Evgueni E. Nesterov,*
}

\section{Supporting Information}

General Procedures. All reactions were performed under an atmosphere of dry nitrogen. Melting points were determined in open capillaries and are uncorrected. Column chromatography was performed on silica gel (Sorbent Technologies, $60 \AA$, 40-63 $\mu \mathrm{m}$ ) slurry packed into glass columns. All solvents were additionally purified and dried by standard techniques. High purity $\operatorname{Pd}\left(\mathrm{PPh}_{3}\right)_{4}$ was obtained from Strem Chemicals, Inc. All other reagents were obtained from Aldrich and Alfa Aesar and used without further purification. ${ }^{1} \mathrm{H}$ and ${ }^{13} \mathrm{C}$ NMR spectra were recorded at $300 \mathrm{MHz}$ and 75 $\mathrm{MHz}$ respectively, and are reported in ppm downfield from tetramethylsilane. FT-IR spectra of solid samples were recorded on Bruker Tensor 27 FT-IR spectrometer equipped with a total internal reflection module. UV-visible spectra were recorded on Varian Cary $50 \mathrm{UV}$-Vis spectrophotometer. Fluorescence studies were carried out with a PTI QuantaMaster4/2006SE spectrofluorimeter. Fluorescence quantum yields were determined using ethanol solution of Coumarin 6 as a standard (solution samples, $\Phi=0.78^{1}$ ) and $\sim 1 \mathrm{mM} \mathrm{9,10-diphenylanthracene} \mathrm{in} \mathrm{PMMA} \mathrm{spin-cast} \mathrm{film} \mathrm{(solid}$ films, $\left.\Phi=0.83^{2}\right)$. Cyclic voltammetry $(\mathrm{CV})$ measurements were carried out in a standard 3-electrode electrochemical cell in $0.1 \mathrm{M} \mathrm{Bu}_{4} \mathrm{NPF}_{6}$ solution in $\mathrm{CH}_{2} \mathrm{Cl}_{2}$ as an electrolyte with $3 \mathrm{~mm}$ diameter glassy carbon or $2 \mathrm{~mm}$ diameter Pt button working electrode, Pt wire auxiliary electrode, and $\mathrm{Ag} / \mathrm{Ag}^{+}$ reference electrode using Autolab PGSTAT 302 potentiostat from Eco Chemie. The data were corrected by the $\mathrm{CV}$ of ferrocene performed under the same conditions immediately before and after the measurements. GPC analyses were performed with Agilent 1100 chromatograph equipped with two PLgel $5 \mathrm{~mm}$ MIXED-C columns connected in series, using THF as a mobile phase, and calibrated against polystyrene standards. Polymer samples for fluorescence quenching studies were prepared using Laurell Technologies WS-400B-6NPP spin processor. Scanning Electron Microscopy images were acquired with Hitachi S-3600N microscope. High resolution mass spectra were obtained at the LSU Department of Chemistry Mass Spectrometry Facility using an ESI or MALDI-TOF method, and a peak matching protocol to determine the mass and error range of the molecular ion. 


\section{Synthetic details.}

2,5-diiodo-1,4-hydroquinone (4) was prepared as described in the literature. ${ }^{3}$

1,4-Bis((diethylene glycol monomethyl ether)oxy)-2,5-diiodobenzene (5). A mixture of 14.5 $\mathrm{g}(0.04 \mathrm{~mol})$ of $4,43.8 \mathrm{~g}(0.16 \mathrm{~mol})$ of diethylene glycol monomethyl ether $p$-toluenesulfonate, ${ }^{4} 22.1$ $\mathrm{g}(0.16 \mathrm{~mol})$ of $\mathrm{K}_{2} \mathrm{CO}_{3}$, and $0.66 \mathrm{~g}(0.04 \mathrm{~mol})$ of $\mathrm{KI}$ in $500 \mathrm{ml}$ of methyl ethyl ketone was stirred at $100{ }^{\circ} \mathrm{C}$ for $48 \mathrm{~h}$. After concentrating in vacuo, the dark brown residue was dissolved in $\mathrm{CH}_{2} \mathrm{Cl}_{2}$, and the solution was washed successively with $10 \%$ aqueous $\mathrm{KOH}$ solution, water and brine, and dried over $\mathrm{Na}_{2} \mathrm{SO}_{4}$. Concentration in vacuo afforded crude product as a brown solid, which was recrystallized from $n$-heptane - toluene mixture to give $18.4 \mathrm{~g}(81 \%)$ of 5 as a light-brown crystalline material, mp 90-92 ${ }^{\circ} \mathrm{C} .{ }^{1} \mathrm{H}$ NMR $\left(\mathrm{CDCl}_{3}\right) \delta 7.25$ (s, 2H), 4.14-4.10 (m, 4H), 3.91-3.87 (m, 4H), 3.81$3.77(\mathrm{~m}, 4 \mathrm{H}), 3.61-3.57(\mathrm{~m}, 4 \mathrm{H}), 3.41(\mathrm{~s}, 6 \mathrm{H})$. HRMS m/e $588.9569(\mathrm{M}+\mathrm{Na})^{+}$(calcd for $\mathrm{C}_{16} \mathrm{H}_{24} \mathrm{O}_{6} \mathrm{NaI}_{2}$ 588.9560).

1,4-Bis((diethylene glycol monomethyl ether)oxy)-2,5-diethynylbenzene (6). A mixture of $17.0 \mathrm{~g}(0.03 \mathrm{~mol})$ of $5,8.8 \mathrm{~g}(12.6 \mathrm{ml}, 0.09 \mathrm{~mol})$ of (trimethylsilyl)acetylene, $1.44 \mathrm{~g}(7.5 \mathrm{mmol})$ of $\mathrm{CuI}$, and $0.69 \mathrm{~g}(6.0 \mathrm{mmol})$ of $\mathrm{Pd}\left(\mathrm{PPh}_{3}\right)_{4}$ in $350 \mathrm{ml}$ of toluene $-i \mathrm{Pr}_{2} \mathrm{NH}(7: 3)$ mixture was stirred at 70 ${ }^{\circ} \mathrm{C}$ in a sealed flask for $48 \mathrm{~h}$. After cooling down to room temperature, the mixture was passed through a short column with silica gel eluted with $\mathrm{CHCl}_{3}$. The solution was concentrated in vacuo, the resulting residue was dissolved in $200 \mathrm{ml}$ of methanol, and added dropwise to a solution of $4.0 \mathrm{~g}(0.07$ $\mathrm{mol}$ ) of $\mathrm{KOH}$ in $500 \mathrm{ml}$ of methanol. After stirring for $40 \mathrm{~min}$, the mixture was poured into water, extracted with ether, the organic phase was washed successively with water, conc. $\mathrm{NH}_{4} \mathrm{Cl}$ solution, water, brine, and dried over $\mathrm{Na}_{2} \mathrm{SO}_{4}$. Concentration in vacuo afforded solid material, which was dissolved in ethyl acetate - hexane (2:1) mixture and passed through a short column with silica gel. After concentration in vacuo, the resulting solid was recrystallized from hexane $-\mathrm{CH}_{2} \mathrm{Cl}_{2}$ mixture to give $4.4 \mathrm{~g}(41 \%)$ of 6 as a brown crystalline material, mp 88-90 ${ }^{\circ} \mathrm{C} .{ }^{1} \mathrm{H}$ NMR $\left(\mathrm{CDCl}_{3}\right) \delta 7.01(\mathrm{~s}, 2 \mathrm{H})$, 4.19-4.16 (m, 4H), 3.90-3.87 (m, 4H), 3.78-3.75 (m, 4H), 3.59-3.56 (m, 4H), 3.40 (s, 6H), 3.32 (s, 2H).

\section{1,4-Bis((diethylene glycol monomethyl ether)oxy)-2,5-bis((4,4,5,5-tetramethyl-1,3,2-} dioxaborolan-2-yl)ethen-1-yl)benzene (7). A mixture of $2.26 \mathrm{~g}(6.24 \mathrm{mmol})$ of $6,1.75 \mathrm{~g}(2.00 \mathrm{ml}$, $13.7 \mathrm{mmol})$ of pinacolborane, and $0.16 \mathrm{~g}(0.62 \mathrm{mmol})$ of $\mathrm{ZrCp}_{2} \mathrm{HCl}$ in $25 \mathrm{ml}$ of 1,2-dichloroethane was stirred in a sealed flask at $65{ }^{\circ} \mathrm{C}$ for $72 \mathrm{~h}$. After cooling down to RT, the reaction mixture was poured into water, and extracted with ether. The organic phase was washed with water, brine, and dried over $\mathrm{Na}_{2} \mathrm{SO}_{4}$. Concentration in vacuo afforded crude product as brown oil. The crude product 
was passed through a column with silica gel eluted with ethyl acetate - hexane (3:1) to afford a yellow solid. Final recrystallization from hexane $-\mathrm{CH}_{2} \mathrm{Cl}_{2}$ afforded $2.1 \mathrm{~g}(54 \%)$ of 7 as a bright-yellow crystalline material, mp 124-126 ${ }^{\circ} \mathrm{C} .{ }^{1} \mathrm{H} \mathrm{NMR}\left(\mathrm{CDCl}_{3}\right) \delta 7.72(\mathrm{~d}, J=20.0 \mathrm{~Hz}, 2 \mathrm{H}), 7.10(\mathrm{~s}, 2 \mathrm{H}), 6.15$ $(\mathrm{d}, J=20.0 \mathrm{~Hz}, 2 \mathrm{H}), 4.17-4.13(\mathrm{~m}, 4 \mathrm{H}), 3.90-3.87(\mathrm{~m}, 4 \mathrm{H}), 3.77-3.74(\mathrm{~m}, 4 \mathrm{H}), 3.62-3.59(\mathrm{~m}, 4 \mathrm{H})$, $3.42(\mathrm{~s}, 6 \mathrm{H}), 1.31(\mathrm{~s}, 24 \mathrm{H})$. HRMS m/e $641.3634(\mathrm{M}+\mathrm{Na})^{+}$(calcd for $\mathrm{C}_{32} \mathrm{H}_{52} \mathrm{~B}_{2} \mathrm{NaO}_{10} 641.3644$ ).

(2,4,6-Triisopropylphenyl)methanol (9a). A solution of $t$-BuLi (6.24 $\mathrm{ml}$ of $1.7 \mathrm{M}$ solution in pentane, $10.6 \mathrm{mmol})$ was added dropwise to a stirred at $-75^{\circ} \mathrm{C}$ solution of $1.0 \mathrm{~g}(3.5 \mathrm{mmol})$ of $2,4,6-$ triisopropylbromobenzene 8 in $30 \mathrm{ml}$ of THF. The resulting mixture was stirred for $1 \mathrm{~h}$ at $-75^{\circ} \mathrm{C}$, followed by dropwise addition of $0.111 \mathrm{~g}(3.7 \mathrm{mmol})$ of paraformaldehyde in $10 \mathrm{ml}$ of THF. The reaction mixture was stirred at $-75^{\circ} \mathrm{C}$ for $1 \mathrm{~h}$, and allowed to warm to room temperature overnight. It was poured into conc. $\mathrm{NH}_{4} \mathrm{Cl}$ solution, and extracted with ether. The combined organic phase was washed with water, brine, and dried over $\mathrm{Na}_{2} \mathrm{SO}_{4}$. After concentration in vacuo, the resulting crude product was passed through a column with silica gel eluted with ethyl acetate - hexane (1:2) mixture. This afforded $0.6 \mathrm{~g}(72 \%)$ of $9 \mathrm{a}$ as a colorless crystalline material, mp 95-96 ${ }^{\circ} \mathrm{C} .{ }^{1} \mathrm{H} \mathrm{NMR}\left(\mathrm{CDCl}_{3}\right) \delta$ 7.05 (s, 2H), 4.78 (d, $J=5.3 \mathrm{~Hz}, 2 \mathrm{H}), 3.38$ (septet, $J=7.0 \mathrm{~Hz}, 2 \mathrm{H}), 2.89$ (septet, $J=7.0 \mathrm{~Hz}, 1 \mathrm{H}$ ), 1.29 $(\mathrm{d}, J=7.0 \mathrm{~Hz}, 12 \mathrm{H}), 1.22$ (d, $J=7.0 \mathrm{~Hz}, 6 \mathrm{H}), 1.19(\mathrm{t}, J=5.0 \mathrm{~Hz}, 1 \mathrm{H})$. HRMS m/e 257.1887 $(\mathrm{M}+\mathrm{Na})^{+}$(calcd for $\left.\mathrm{C}_{16} \mathrm{H}_{26} \mathrm{ONa} 257.1875\right)$.

2,5-Diiodobenzoyl chloride (10). A mixture of $4.0 \mathrm{~g}(10.8 \mathrm{mmol})$ of 2,5-diiodobenzoic acid and $5.0 \mathrm{ml}(68.7 \mathrm{mmol})$ of thionyl chloride was refluxed for $2 \mathrm{~h}$. After allowing to cool down to RT, unreacted thionyl chloride was distilled out, and the crude product was recrystallized from hexane to afford $3.7 \mathrm{~g}(88 \%)$ of $\mathbf{1 0}$ as a colorless crystalline material, mp 93-94 ${ }^{\circ} \mathrm{C} .{ }^{1} \mathrm{H} \mathrm{NMR}\left(\mathrm{CDCl}_{3}\right) \delta 8.31(\mathrm{~d}$, $J=2.0 \mathrm{~Hz}, 1 \mathrm{H}), 7.75(\mathrm{~d}, J=8.3 \mathrm{~Hz}, 1 \mathrm{H}), 7.56\left(\mathrm{dd}, J_{1}=8.3, J_{2}=2.0 \mathrm{~Hz}, 1 \mathrm{H}\right)$.

2,4,6-Triisopropylbenzyl 2,5-diiodobenzoate (11a). A mixture of $0.84 \mathrm{~g}(2.1 \mathrm{mmol})$ of $\mathbf{1 0}$, $0.50 \mathrm{~g}(2.1 \mathrm{mmol})$ of $9 \mathrm{a}$, and $0.29 \mathrm{~g}(2.4 \mathrm{mmol})$ of 4 - $(N, N$-dimethylamino $)$ pyridine in $40 \mathrm{ml}$ of $\mathrm{CH}_{2} \mathrm{Cl}_{2}$ was stirred at room temperature for $24 \mathrm{~h}$. The reaction mixture was poured into $10 \%$ aqueous $\mathrm{HCl}$, extracted with ether, washed with conc. $\mathrm{NH}_{4} \mathrm{Cl}$ solution, water and brine, and dried over $\mathrm{Na}_{2} \mathrm{SO}_{4}$. Concentration in vacuo afforded white solid which was recrystallized from hexane to yield $1.0 \mathrm{~g}(80 \%)$ of 11a as a colorless crystalline material, mp $115-117^{\circ} \mathrm{C} .{ }^{1} \mathrm{H} \mathrm{NMR}\left(\mathrm{CDCl}_{3}\right) \delta 8.02(\mathrm{~d}, J=2.2 \mathrm{~Hz}, 1 \mathrm{H})$, $7.68(\mathrm{~d}, J=8.4 \mathrm{~Hz}, 1 \mathrm{H}), 7.43\left(\mathrm{dd}, J_{1}=8.4, J_{2}=2.2 \mathrm{~Hz}, 1 \mathrm{H}\right), 7.08(\mathrm{~s}, 2 \mathrm{H}), 5.50$ (s, 2H), 3.30 (septet, $J$ $=6.9 \mathrm{~Hz}, 2 \mathrm{H}), 2.92$ (septet, $J=7.0 \mathrm{~Hz}, 1 \mathrm{H}), 1.29$ (d, $J=6.9 \mathrm{~Hz}, 12 \mathrm{H}), 1.28(\mathrm{~d}, J=7.0 \mathrm{~Hz}, 6 \mathrm{H})$. HRMS m/e $613.0052(\mathrm{M}+\mathrm{Na})^{+}$(calcd for $\mathrm{C}_{23} \mathrm{H}_{28} \mathrm{O}_{2} \mathrm{NaI}_{2}$ 613.0071). 
Benzyl 2,5-diiodobenzoate (11b) was prepared following the procedure for compound 11a. Reaction of $0.62 \mathrm{~g}(1.58 \mathrm{mmol})$ of $\mathbf{1 0}, 0.17 \mathrm{~g}(0.16 \mathrm{ml}, 1.58 \mathrm{mmol})$ of benzyl alcohol $\mathbf{9 b}$, and $0.22 \mathrm{~g}$ (1.80 mmol) of 4-(N,N-dimethylamino)pyridine in $30 \mathrm{ml}$ of $\mathrm{CH}_{2} \mathrm{Cl}_{2}$ afforded, after column chromatography purification, $0.51 \mathrm{~g}(70 \%)$ of $\mathbf{1 1 b}$ as a colorless oil. ${ }^{1} \mathrm{H}$ NMR $\left(\mathrm{CDCl}_{3}\right) \delta 8.09(\mathrm{~d}, J=$ $1.3 \mathrm{~Hz}, 1 \mathrm{H}), 7.69(\mathrm{~d}, J=8.3 \mathrm{~Hz}, 1 \mathrm{H}), 7.50-7.30(\mathrm{~m}, 6 \mathrm{H}), 5.37$ (s, 2H). HRMS m/e $464.8849(\mathrm{M}+\mathrm{H})^{+}$ (calcd for $\mathrm{C}_{14} \mathrm{H}_{11} \mathrm{O}_{2} \mathrm{I}_{2} 464.8848$ )

1,3,5-Triiodobenzene (12) was prepared following the literature procedure, ${ }^{5} \mathrm{mp} 182-185^{\circ} \mathrm{C}$ (lit. ${ }^{6} \mathrm{mp} 183^{\circ} \mathrm{C}$ ).

Polymer P1. A mixture of $100 \mathrm{mg}(0.162 \mathrm{mmol})$ of 7, $39.5 \mathrm{mg}(0.070 \mathrm{mmol})$ of 5, $10.3 \mathrm{mg}$ $(0.017 \mathrm{mmol})$ of $11 \mathrm{a}, 21.7 \mathrm{mg}(0.048 \mathrm{mmol})$ of 12, $4.0 \mathrm{mg}(0.0035 \mathrm{mmol})$ of $\mathrm{Pd}\left(\mathrm{PPh}_{3}\right)_{4}, 134 \mathrm{mg}(0.97$ $\mathrm{mmol})$ of $\mathrm{K}_{2} \mathrm{CO}_{3}$, and $200 \mathrm{mg}(0.69 \mathrm{mmol})$ of sodium dodecyl sulfate in $30 \mathrm{ml}$ of water - toluene ethanol $(10: 1: 4)$ mixture was stirred at $1000 \mathrm{rpm}$ in a sealed Schlenk flask at $75^{\circ} \mathrm{C}$ for $72 \mathrm{~h}$. After cooling down to room temperature, the reaction mixture was poured into acetone, centrifuged, and supernatant solution was discarded. The solid residue was transferred into water, ultrasonicated for 40 min, separated, and washed successively with water, methanol, and acetone, each time upon ultrasonication. Finally, the product was dried in vacuo to afford $40 \mathrm{mg}$ (50\%) of the polymer P1 as a red powder.

Polymer P2. A solution of lithium $n$-propyl mercaptide $(1.0 \mathrm{ml}$ of $\sim 0.5 \mathrm{M}$ solution in HMPA, prepared as described in literature ${ }^{7}$ ) was added to the polymer P1 (25 mg) suspended in $5 \mathrm{ml}$ of HMPA placed in a Schlenk flask. The flask was sealed, and the reaction mixture was ultrasonicated at room temperature for $1.5 \mathrm{~h}$. The resulting mixture was poured into methanol, supernatant solution was removed by centrifugation, and the solid residue was washed with methanol. The solid product was refluxed with a mixture of $20 \mathrm{ml}$ of methanol and $1 \mathrm{ml}$ of conc. $\mathrm{HCl}$ for $24 \mathrm{~h}$, separated, and washed with boiling methanol in a Soxhlett extractor. This was followed by washing successively with methanol and acetone, each time upon ultrasonication. The resulting product was dried in vacuo. This afforded $14 \mathrm{mg}$ (60\%) of $\mathbf{P 2}$ as an orange powder.

Polymer P3. The polymer was prepared following the procedure for polymer P1. Reaction of $100.0 \mathrm{mg}(0.162 \mathrm{mmol})$ of $7,71.9 \mathrm{mg}(0.127 \mathrm{mmol})$ of $5,18.7 \mathrm{mg}(0.032 \mathrm{mmol})$ of $11 \mathrm{a}, 4.0 \mathrm{mg}$ $(0.0035 \mathrm{mmol})$ of $\mathrm{Pd}\left(\mathrm{PPh}_{3}\right)_{4}, 134 \mathrm{mg}(0.97 \mathrm{mmol})$ of $\mathrm{K}_{2} \mathrm{CO}_{3}$, and $200 \mathrm{mg}$ of sodium dodecyl sulfate in $30 \mathrm{ml}$ of water - toluene - ethanol (10:1 : 4) mixture afforded $20 \mathrm{mg}(20 \%)$ of the polymer P3 as a red powder. ${ }^{1} \mathrm{H}$ NMR $\left(\mathrm{CDCl}_{3}\right) \delta 7.47$ (br. s, 2H), 7.21 (s, 2H), 4.39-4.10 (m, 4H), 4.10-3.85 (m, 4H), 3.85-3.68 (m, 4H), 3.68-3.46 (m, 4H), 3.39 (br. s, 6H). The spectrum also shows signals belonging to 
the template. Integration of the template signals at $5.53(\mathrm{~s}, 2 \mathrm{H}$ of template) and $1.28(\mathrm{~m}, 18 \mathrm{H}$ of template) allowed to estimate the fraction of the template to be $\sim 10 \%$. GPC analysis: $M_{n} 9500 \mathrm{Da}$, PDI 1.65.

Polymer P4. The polymer was prepared starting from $10 \mathrm{mg}$ of polymer $\mathbf{P 3}$ following the procedure for polymer P2. This yielded $5 \mathrm{mg}(50 \%)$ of the polymer $\mathbf{P 4}$ as an orange powder. ${ }^{1} \mathrm{H}$ NMR $\left(\mathrm{CDCl}_{3}\right) \delta 7.43(\mathrm{~d}, \mathrm{~J} \sim 14 \mathrm{~Hz}, 2 \mathrm{H}), 7.18$ (br. s), 4.39-4.10 (m, 4H), 4.10-3.85 (m, 4H), 3.85-3.68 (m, $4 \mathrm{H}), 3.68-3.46$ (m, 4H), 3.37 (br. s, $6 \mathrm{H})$. The template was not detectable by ${ }^{1} \mathrm{H}$ NMR analysis. GPC analysis: $M_{n} 12500 \mathrm{Da}, \mathrm{PDI} 2.06$.

Polymers P5 and P6. The polymer P5 was prepared following the procedure described for the polymer P1. Reaction of $60.0 \mathrm{mg}(0.097 \mathrm{mmol})$ of 7, $23.8 \mathrm{mg}(0.042 \mathrm{mmol})$ of 5, $4.6 \mathrm{mg}(0.010 \mathrm{mmol})$ of $11 \mathrm{~b}, 13.2 \mathrm{mg}(0.029 \mathrm{mmol})$ of $12,3.35 \mathrm{mg}(0.0029 \mathrm{mmol})$ of $\mathrm{Pd}\left(\mathrm{PPh}_{3}\right)_{4}, 80.3 \mathrm{mg}(0.582 \mathrm{mmol})$ of $\mathrm{K}_{2} \mathrm{CO}_{3}$, and $150 \mathrm{mg}$ of sodium dodecyl sulfate in $20 \mathrm{ml}$ of water - toluene - ethanol (10: $\left.1: 4\right)$ mixture afforded $15 \mathrm{mg}(50 \%)$ of the polymer P5 as an orange-red powder. This polymer (10 mg) was converted to $\mathbf{P 6}$ following the procedure for the polymer P2. This yielded $6 \mathrm{mg}(60 \%)$ of $\mathbf{P 6}$ as an orange powder.

2,4,6-Trinitrotoluene (TNT) and 1-tert-butyl-2,4-dinitrobenzene (BDNB) were prepared according to literature procedures. ${ }^{8,9}$ Caution: TNT is high explosive and should be handled only in small quantities.

\section{Vapor phase fluorescence quenching studies.}

Polymers were spin-cast from $\sim 1 \mathrm{mg} / \mathrm{ml}$ solutions in $\mathrm{CHCl}_{3}$ (for $\mathbf{P 3}$ and $\mathbf{P 4}$ ) or from $\sim 1 \mathrm{mg} / \mathrm{ml}$ suspensions in $\mathrm{CHCl}_{3}$ (for $\mathbf{P 2}$ and P6) on $22 \times 22 \mathrm{~mm}$ microscope glass cover slides at $2500 \mathrm{rpm}$ in nitrogen atmosphere. A polymer-covered slide was attached inside a $40 \times 40 \times 10 \mathrm{~mm}$ quartz fluorescent cell containing cotton wool mixed with a solid quencher at the bottom. The cell was immediately capped and placed into a sample compartment of a spectrofluorimeter, and fluorescence spectra were automatically recorded at specified time intervals, using a customized program written in Macro Command Editor of PTI FeliX32 software. 


\section{Additional figures.}

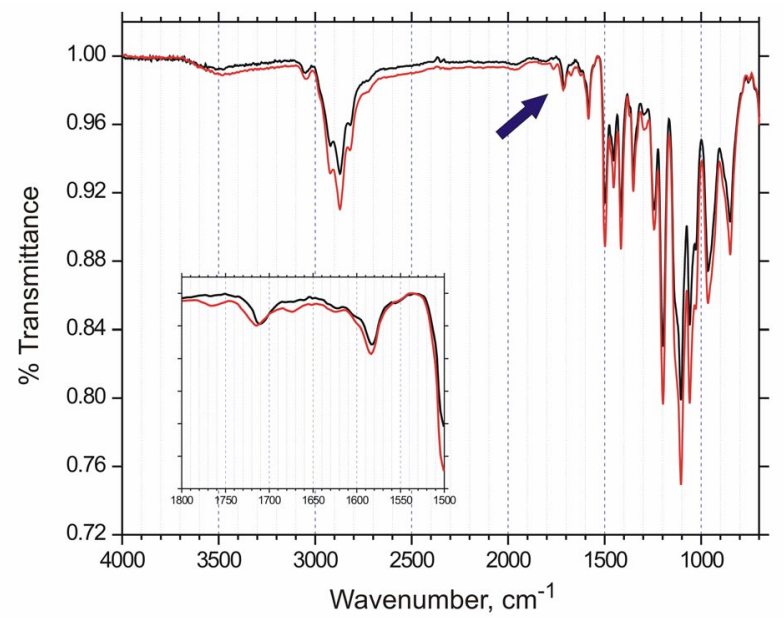

Figure S1. FT-IR spectra of the polymers P5 and P6. Black trace corresponds to the polymer before template removal (P5), red trace corresponds to the MICP P6. The carbonyl stretching frequency bands used to determine the extent of template removal are shown with blue arrows, and the area around this signal is expanded in the inset. The frequency shift is $\sim 6 \mathrm{~cm}^{-1}$.

\section{References.}

(1) Reynolds, G. A.; Drexhage, K. H. Opt. Commun. 1975, 13, 222-225.

(2) Osaheni, J. A.; Jenekhe, S. A. J. Am. Chem. Soc. 1995, 117, 7389-7398.

(3) Zhou, Q.; Swager, T. M. J. Am. Chem. Soc. 1995, 117, 7017-7018.

(4) Snow, A. W.; Foos, E. E. Synthesis 2003, 509-512.

(5) Gan, Z.; Roy, R. Can. J. Chem. 2002, 80, 908-916.

(6) Beinhoff, M.; Karakaya, B.; Schluter, A. D. Synthesis 2003, 79-90.

(7) Bartlett, P. A.; Johnson, W. S. Tetrahedron Lett. 1970, 4459-4462.

(8) Dorey, R. C.; Carper, W. R. J. Chem. Eng. Data 1984, 29, 93-97.

(9) Dangel, B. D.; Godula, K.; Youn, S. W.; Sezen, B.; Sames, D. J. Am. Chem. Soc. 2002, 124, 11856-11857. 